\title{
Human And Nature Resources Management Textbook For Teaching Economic Education Students
}

\author{
Deni Nugroho Setyabudi", Melisa Wahyu Fandyansari**, Theodorus Dangga Wewu*** \\ *Economic Education, IKIP Budi Utomo \\ ** Pendidikan Ekonomi, IKIP Budi Utomo \\ *** Pendidikan Ekonomi, IKIP Budi Utomo \\ DOI: 10.29322/IJSRP.11.01.2021.p10954 \\ http://dx.doi.org/10.29322/IJSRP.11.01.2021.p10954
}

\begin{abstract}
Human and Nature Resources Management Textbook for Teaching Economic Education Students was developed for students. The materials presented in the Human and Nature Resources Management textbook were expected to be able to help in the learning process and facilitate the students in understanding what they wanted to understand. This research was conducted using a research method which according to Borg and Gall has been simplified into seven steps. The test was conducted by three validation experts, they were material expert validation, linguistic expert validation, and media expert validation. Besides, pre-test and post-test were also conducted to 65 students on their sixth semester year 2017. Based on the data result which was gained and processed, there was a difference on the learning outcome. In the pre-test, students got 77.06 as the average score. Meanwhile, in the post-test, students got 85.6 as the average score. Therefore, the media of Human and Nature Resources Management textbook was effective to be used in the teaching and learning process. This statement was proved by the result of pre-test and post-test which were conducted on 65 students.
\end{abstract}

Index Terms- Human and Nature Resources Management, Textbook

\section{INTRODUCTION}

$\mathrm{H}$ igh quality resources can be shown by high performance and productivity. Each organization has various kinds of resources which consist of fund, technology, method or strategy, human, and etc. From the existing various kinds of resource, human or human resource is a very important element. To plan, manage, and control human resource, it needs a managerial tool which is called Human Resource Management. Rivai (Suwanto and Priansa, 2016:9) defined that Human Resource was one of the fields in public management which included planning, organization, implementation, and management aspects. Improving the education quality in each organization needs a leader. The leader plays the role to liven up, drive, and direct to achieve the desired objectives to be achieved. To be able to be a leader who can fulfill those roles, education and teaching media play significant role to shape a leader who can bring his personnel to be better, especially in education institution.

Education is a need which cannot be separated from human life, because the existence of education human can develop all the potentials possessed based on their talent, interest, and willingness. Education also plays the role as a human resource development process to gain the optimal social skill and individual development to give a strong relation among the individual and the society and also the surrounding environment (Ibrahim, 2013:131). Education is more than just teaching; it can be said as a process of delivering knowledge and shaping personality with all aspects that are covered. Therefore, teaching is more into the specialty creating of certain fields (Nurcholis, 2013:25).

Teaching is a process of interaction or delivering information from teacher to students. Teaching process is also a series of teaching activity to gain achievement according to the objectives that have been decided. (Fundyantarto in Baharuddin, 2015:15) defined learning as an activity to gain intelligence or knowledge. The effort to gain an intelligence or knowledge is human effort to fulfill their need in acquiring knowledge or intelligence which are not possessed before. Thus, through learning human knows, 
understands, comprehends, can implement, and has something. Baharuddin (2015:18) proposed several characteristics of learning as follow:

1. Learning is signed by the difference of behavior. It means that the result of learning can be observed from the behavior, which means the difference of behavior from not knowing to knowing, from unskillful to skillful. Without observing behavior as the learning outcome, we will not know the existence of learning outcome.

2. Behavioral changes are relatively permanent. It means that behavioral changes because of learning process for certain period of time will be permanent or not changing. However, the behavioral changes will not be displayed for life.

3. Behavioral changes are not always observed immediately during the process of learning, the behavioral changes are potential.

4. Experience or training can give strength. Something which strengthen will give motivation or drive to change the behavior.

The conducted learning process is usually done by the teacher to the students. The effective learning focuses on the teaching and learning activity which directs to learning objectives achievement which has been determined. This is in line with the statement of Zheng et al (2013) who proposed that the effective teaching activity is the process to finish learning assignment and achieve learning objective in certain expected period of time, so that it can be said that the effective teaching is oriented to the success of learning objectives achievement.

To achieve certain objective in learning activity, the messages delivered in the teaching and learning process have to be able to be accepted by the students. However, sometimes in the teaching and learning activity, the students are less able to absorb the lesson given by the teacher effectively and efficiently. One alternative to overcome the obstacle is by using media in the teaching and learning process. The role of media in the teaching and learning process is very important as the intermediary so that the messages in the teaching and learning process can be delivered to the students effectively and efficiently. By optimizing the use of media, teaching and learning process can occur and achieve the optimal result (Musfiqon in Supriyanta, 2015:13). Ibrahim et al in'Kustiawan (2016:6) define that teaching media is everything used to distribute teaching materials so that it can stimulate the students' attention, interest, thought, and feeling in learning activity to achieve the desired teaching and learning objectives.

Syukur in Rahmaibu (2016:17-18) stated that according to Encyclopedia of Educational Research in teaching and learning technology that the values or significances of teaching media are:

1. Putting the real or concrete basis to think so that it decreases verbalism.

2. Expanding the students' attention.

3. Putting the important basis for the students' learning development.

4. Giving concrete experiences.

5. Growing regular and continuous behavior.

6. Helping the growth of understanding. Therefore, it can help the development of language.

7. Giving the experience for the students which is not gained by other ways.

8. Giving the real concept which is tangible and detail.

9. Generating the motivation and stimulating the learning process.

Teaching media which is used by teachers is a media to become the reference in delivering materials, for example textbook. This research developed Human and Nature Resources Management textbook which can be used by the students especially from economic education department to learn management needed in every performance. The mentioned Human and Nature Resources Management textbook consists of five chapters in which each chapter contains five sub-chapters. The first chapter discussed about Human Resource Management Concept. This chapter consists of five sub-chapters which covered about: 1) The Definition of Human Resource Management, 2) The Objectives of Human Resource Management, 3) The Function of 
Human Resource Management, 4) External Environment Challenges, and 5) Organizational Challenges. The second chapter discussed about Human Resource Planning in which the sub-chapters explain about: 1) The Definition of Human Resource Planning, 2) The Objectives of Human Resource Planning, 3) The Significances of Human Resource Planning, 4) The Process of Human Resource Planning, and 5) Various Challenges in the Field of Human Resource.

The third chapter explained about Human Resource Recruitment. Each sub-chapter elaborated about: 1) The Definition of Recruitment, 2) The Objectives of Recruitment, 3) The Requirements of Selection and Job Positioning, 4) Various Obstacles in Recruitment, and 5) The Result of Selection and Feedback. The fourth chapter discussed about Human Resource Development and Training which also has five sub-chapters, they are: 1) The Definition of Human Resource Development and Training, 2) The Objectives, Principles, and Significances of Development, 3) SWOT Analysis in Human Resource Development, 4) Significance and Process of Training, and 5) Human Resource Sustainability. Next is the last chapter which discussed about Career Planning and Work Achievement Assessment. Each chapter discussed about: 1) The Roles of Human Resource Development Department, 2) Career Development, 3) The Preparation of Work Achievement Assessment System, 4) Past Work Achievement Assessment, and 5) Assessment with Future Orientation. The materials presented in Human and Nature Resources Management textbook were expected to be able to help in the process of learning and facilitate the students to comprehend what they want to understand.

\section{RESEARCH METHOD}

The research method of this study was Research and Development. In this study, the focus was the process of developing a certain product which wanted to be developed by the researchers that was conducted through a research using various methods and several steps. The steps used by the researchers were Borg and Gall's which has been simplified to seven steps, they were: 1) Research and Information Collection; 2) Planning; 3) Develop Preliminary Form of Product; 4) Preliminary Field Testing; 5) Main Product Revision; 6) Main Field Testing; and 7) Operation Product Revision. The steps chosen was adapted to the researchers' needs.

The subjects of the testing done to three experts, they were material expert, linguistic expert, and media expert. Then, pre-test and post-test were conducted to 65 students of the sixth semester year 2017. The data collection technique employed questionnaire, interview, test, and document methods.

\section{FINDINGS AND DISCUSSION}

Before the product was tried out, the product was validated by material expert, linguistic expert, and media expert. Expert validation was done with the purpose of developing this product and appropriate to be tried out to the students. Besides, expert validation could also overcome errors and weaknesses on the material and did not have many errors and met the students' need. After the researchers tried out the textbook to the students through pre-test and post-test, a difference in the learning outcome was found based on the data result gained and after being processed. In the pre-test, the students got 77.06 as the average score. Meanwhile, in the post-test, the students got 85.6 as the average score. The use of pre-test and post-test methods in teaching and learning process aimed at being a controller of the learning outcome so that the students would be more able to understand the learning materials easily which was able to measure how far the students' competence progressed after using the textbook media.

Human and Nature Resources Management textbook media was categorized as effective if being used in the teaching and learning process. This statement was proven by pre-test and post-test results which were conducted to 65 students. According to Daryanto (in Kanti et al, 2018:140), a teaching media can be said as effective if it can improve the achievement of teaching and learning objectives. The achievement level of the objectives was in the form of the improvement on knowledge and skill and 
behavioral development in teaching and learning process. Thus, it can be concluded that Human and Nature Resources Management textbook media was effective if being used in the teaching and learning process of Human and Nature Resources Management subject.

\section{CONCLUSION}

Based on the research conducted to develop Human and Nature Resources Management Textbook for Teaching Economic Education Students was done through a study using a method by Borg and Gall which has been simplified into seven steps. In conducting try-out to 65 students, the researchers employed pre-test and post-test. From the data result gained and processed, there was a difference on the learning outcome. In the pre-test, the students got 77.06 as the average score. Meanwhile, in the post-test, the students got 85.6 as the average score. The use of pre-test and post-test methods in teaching and learning process aimed at being a controller of learning achievement so that the students would be more able to understand the learning materials easily which could measure how far the students' competence after using the textbook media. Human and Nature Resources Management Textbook Media can be categorized as effective if it was used in the process of teaching and learning. This statement was proven by the result of pre-test and post-test which were conducted to 65 students.

\section{REFERENCES}

[1] Baharuddin \& Wahyuni, Esa Nur. 2015. Teori Belajar dan Pembelajaran. Yogyakarta: Ar-Ruzz Media.

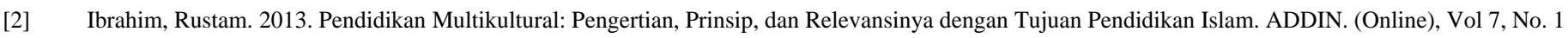

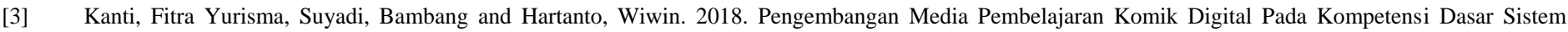
Pembayaran dan Alat Pembayaran Untuk Siswa Kelas X IPS di MAN 1 Jember. Jurnal Pendidikan Ekonomi: Jurnal Ilmiah Ilmu Pendidikan, Ilmu Ekonomi, dan Ilmu Sosial, (Online), Vol. 12, No. 1, ISSN. 1907-9990

[4] Kustiawan, Usep. 2016. Pengembangan Media Pembelajaran Anak Usia Dini. Malang: Gunung Samudera'

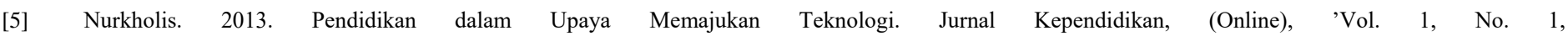
(http://ejournal.iainpurwokerto.ac.id/index.php/jurnalkependidikan/article/download/530/473/, diakses'19 Januari 2020 pukul 08:44)

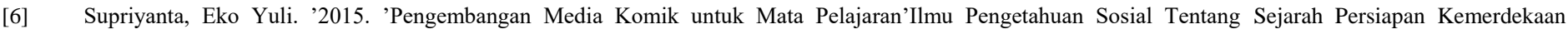
Indonesia pada Kelas V SD Muhammadiyah Mutihan Wates Kulon Progo. Skripsi tidak diterbitkan. Yogyakarta: Universitas Negeri Yogyakarta Suwanto and Priansa, D.J. 2016. Manajemen SDM dalam Organisasi Publik dan Bisnis. Bandung: Alfabeta

\section{AUTHORS}

First Author - Deni Nugroho Setyabudi, lecturer, Economic Education IKIP Budi Utomo, deninugrohosetyabudi@budiutomomalang.ac.id

Second Author - Melisa Wahyu Fandyansari, lecturer, Economic Education IKIP Budi Utomo, melisawahyufandyansari@budiutomomalang.ac.id.

Third Author - Teodorus Dangga Wewu, student, Economic Education IKIP Budi Utomo, teodorusdanggawewu03@gmail.com.

Correspondence Author - Melisa Wahyu Fandyansari, melisawahyufandyansari@budiutomomalang.ac.id, melisawaf@gmail.com, +6281231192012 . 